\title{
Status of weed control in imidazolinone-herbicide resistant rice in Rio Grande do Sul
}

\author{
André R. Ulguim ${ }^{\mathrm{a} *} \odot$, Bruno L. Fruet ${ }^{\mathrm{a}}$, Aldo Merotto Junior ${ }^{\mathrm{b}}{ }^{\oplus}$, Anelise L. Silva $^{\mathrm{a}} \odot$ \\ a Universidade Federal de Santa Maria, Santa Maria, RS, Brazil. ' Universidade Federal do Rio Grande do Sul, Porto Alegre, RS, Brazil.
}

Abstract: Background: Rice fields in the state of Rio Grande do Sul (RS) are one of the largest areas where the herbicide resistant system is utilized worldwide. Weed management is important to achieve high rice yields, and herbicide resistance is the main limiting factor. Knowledge of practices used by farmers is important to understand the dynamics of weeds in rice fields.

Objective: To evaluate the frequency of utilization of weed management practicesand themainconsequencesrelated toherbicideresistanceassociated with the utilization of the imidazolinone-herbicide resistant rice in RS. Methods: The study was carried out during the 2017/2018 season based on a survey of 103 consultants about weed management in the Clearfield ${ }^{\circ}$ flooded rice system. Data were analyzed by nonmetric multidimensional scaling (NMDS) and word cloud analysis.

\begin{abstract}
Results: The main weeds in Clearfield $^{\circ}$ rice are weedy rice and barnyardgrass, with Cyperus sp. also mentioned. Currently the main reasons for low weed control efficacy are resistance to herbicides, delay in beginning the flooding and application to plants at advanced developmental stages. The consultants' perceptions indicate that the number of cases of herbicide resistance and area are increasing to several weed species and herbicide modes of action. The predominant rice establishment system is minimum tillage. Conclusions: Barnyardgrass and weedy rice are still a problem after 15 years of utilization of the imidazolinone-herbicide resistance system, and the adoption of best herbicide practices and integrated weed management is necessary in the rice crop in RS.
\end{abstract}

Keywords: Clearfield System ${ }^{\circledast}$; Herbicide resistance; Imidazolinones; Integrated weed management

Journal Information:

ISSN - 2675-9462

Website: http://awsjournal.org

Journal of the Brazilian Weed

Science Society

How to cite: Ulguim AR, Fruet BL, Merotto Junior A, Silva AL. Status of weed control in imidazolinoneherbicide resistant rice in Rio Grande do Sul. Adv Weed Sci. 2021;39:e237355.

https://doi.org/10.51694/AdvWeedSci/2021;39:00007

Approved by:

Editor in Chief: Carlos Eduardo Schaedler

Conflict of interest: The authors declare that there is no conflict of interest regarding the publication of this manuscript.

Received: April 29, 2020

Accepted: December $1^{\text {st }}, 2020$

* Corresponding author: <andre.ulguim@ufsm.br>

\section{(c) (1)}

This is an open-access article distributed under the terms of the

Creative Commons Attribution License, which permits unrestricted use, distribution, and reproduction in any medium, provided that the original author and source are credited.

Copyright: 2021

\section{Introduction}

Weed management of flooded rice (Oryza sativa L.) in Rio Grande do Sul (RS) is predominantly based on using cultivars resistant to the chemical group of imidazolinones that is called Clearfield ${ }^{\circ}$ Production System (Agro Basf Brasil, 2020). The mode of action of these herbicides is to inhibit the activity of the acetolactate synthase (ALS) enzymes. The area currently occupied by the Clearfield ${ }^{\circ}$ system in RS is estimated as $83 \%$ of the total 1.1 million ha cultivated area (Conab, 2020). The first commercial cultivar of Clearfield ${ }^{\circ}$ rice was IRGA 422CL, available to producers in the 2003-2004 growing season (Marchesan et al., 2011). Thus, in 2018, the use of the Clearfield $^{\circ}$ technology in Brazil completed fifteen years with several impacts on the rice production system.

The Clearfield ${ }^{\circ}$ System enabled selective, chemical control of weedy rice, and is considered the main tool for the management of this species in irrigated rice fields (Marchesan et al., 2011; Menezes et al., 2009). However, due to the exclusive use of this technology continuously for several years and also the use of other ALS-inhibitor herbicides, weeds evolved resistance to this mode of action, resulting in difficulties for management and increasing production costs (Ulguim et al., 2019). The first identification of imidazolinone-resistant weedy rice in RS occurred after two or three years using the Clearfield ${ }^{\circ}$ System (Menezes et al., 2009). Nowadays, there are five weed species reported as resistant to ALS-inhibitors (Heap, 2020), which has changed the management practices compared with the first years of Clearfield ${ }^{\circ}$ System use. This situation is associated with monocultures and mainly with the repetitive use of herbicides with the same mode of action (Ulguim et al., 2017).

Several factors have been related to the evolution of herbicide resistance in rice fields cultivated with the Clearfield system. The first herbicide resistance problem of this system was the occurrence of weedy rice resistance originated mainly from gene flow from the resistant rice varieties and spread through contaminated rice seeds (Goulart et al., 2016). After that, farmers became more conscious of the importance of using certified seeds, crop rotation, use of burndown herbicides at the $S_{3}$ plant stage (Counce et al., 2000), and use of imidazolinones at pre and post-emergence (Merotto Junior et al., 2016, Ulguim et al., 2019). These practices increase the efficacy and sustainability of weedy rice control. However, another herbicide resistance problem occurred related to the resistance of Echinochloa sp. to the imidazolinone herbicides caused by mutations on the ALS gene (Matzenbacher et al., 2015). 
Nowadays, the problem of herbicide resistance in Echinochloa sp. is considered even more important than the previous case of weedy rice (Fruet et al., 2020). Multiple herbicide resistance to quinclorac, ALS and ACCase inhibitors was identified in Echinochloa sp. (Eberhardt et al., 2016). The intensity of the problems caused by these weeds is affected by several cultivation and weed management practices (Menezes et al., 2009; Riar et al., 2013a; Ulguim et al., 2018). However, the perception and the frequency of utilization of these practices are not documented in largescale studies in the rice growing area in RS.

Farmers have a good understanding of weed management strategies to prevent herbicide resistance, even though few of them have implemented the adequate strategies before a critical event promotes the paradigm break (Beckie and Hall, 2014; Edwards et al., 2014). Further, research studies have updated information about weed species occurrence and weed control practices (Riar et al., 2013b). In this sense, the Clearfield ${ }^{\circ}$ Production System changed the weed management of rice since the first use, but the long-term consequences of these changes are poorly understood by farmers and consultants. A study focused on the diagnosis of the herbicide use pattern, occurrence of the weed species and individual utilization of crop practices in rice areas in southern Brazil was recently performed (Fruet et al., 2020). The present study is a multivariate analysis focused on broad weed management practices and farmland use. The objective of this study was to evaluate the frequency of utilization of weed management practices and the main consequences of herbicide resistance associated with the utilization of the imidazolinone-herbicide resistant rice in RS.

\section{Material and methods}

The study was carried out during the 2017/2018 season. The survey was performed with crop consultants on weed management in flooded rice cropping system areas, including Clearfield $^{\circ}$ and non-Clearfield ${ }^{\circ}$ areas but that have had herbicide resistant rice at least once. A consultant was also surveyed who works with different rice crop systems. A total of 103 surveys were obtained from all rice-producing regions in RS State (Figure 1). The total area covered by those consultants was 862,080 ha, which represents approximately $80 \%$ of the flooded rice area in RS during the season evaluated (Conab, 2018).

Crop consultants for flooded rice fields were asked about predominant weed species, reasons for the low efficacy of weed control, evolution of herbicide resistance, weed species with putative herbicide resistance, field cases of weed resistance by mode of action, establishment of crop systems used on Clearfield ${ }^{\circ}$ areas and land use during the rice off season. A list of predefined answers was used in the questions about weed species and potential reasons for the low control efficacy.

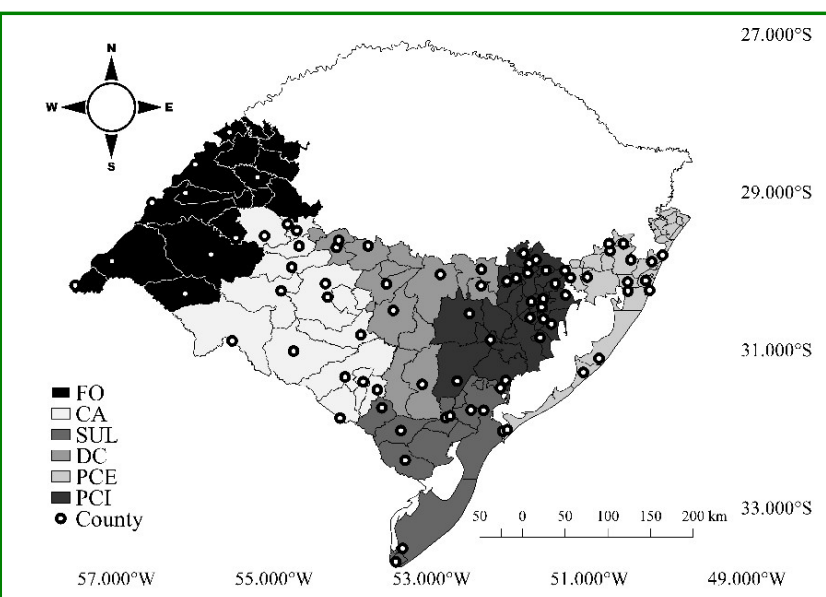

Figure 1 - Flooded rice regions in Rio Grande do Sul (RS) and counties represented in the survey. Note: FO: Fronteira Oeste; CA: Campanho; SUL: Zono Sul; DC: Depressõo Central; PCE: Planície Costeira Externa; PCl: Planície Costeiro Interno. Map generated using QGIS ver. 2.18.14 (QGIS Development Team, 2019. QGIS Geographic Information System. Open Source Geospatial Foundation. http://qgis.osgeo.org).

In these questions, the respondents were asked to rate each answer on a scale of 1 to 5 , with $1=$ not important, 2 = rarely important, 3 = occasionally important, $4=$ important, and 5 = very important, according to Riar et al. (2013a). Other multiple-choice questions required consultants to choose an applicable answer.

The obtained data was analyzed by descriptive statistics and percentages were attributed to the answers. Word cloud graphics using 'WordArt' software (WordArt, 2020) were constructed for questions involving weed species and reasons for low control efficacy. The differences in size and word colors for each species and reasons indicated the frequency of consultant's answers. In order to construct the consultants', perceptual mapping based on answers about species and reasons for low herbicide efficiency, non-metric multidimensional scaling (NMDS) was carried out by using function 'metaMDS' from the 'vegan' package in R software (Oksanen et al., 2018). Stress values in NMDS were estimated to ensure adequate adjustment to a bidimensional space, in which values below 0.25 were considered acceptable. Stress indicates the relation between adjusted dissimilarity matrixes (points) and the observed data. Therefore, the lower the Stress, the more adequate the ordination representation.

The orientation of points in NMDS was arbitrary and the graph displays an arrangement based on the distance of a measure derived from the patterns of objects (consultants and variables). Furthermore, the axes scores are independent and were generated as the weighted averages. Arrow length is proportional to the correlation between the ordination and the variable. Results of multiple-choice questions were converted into a percentage and analyzed by descriptive statistics. 


\section{Results and discussion}

The most cited weeds that occurred in flooded rice areas were weedy rice and barnyardgrass (Figure 2a). Weedy rice has been considered the main weed in several ricegrowing areas worldwide due to limited chemical control, competition for light and nutrients and dispersal with rice seeds. Some characteristics that may increase the competitive ability of this species are high nitrogen use efficiency, high tillering capacity and high seed shattering (Burgos et al., 2006; Nunes et al., 2015). Currently, the only opportunity to selectively control emerged weedy rice in the rice crop is using the Clearfield ${ }^{\circledR}$ Production System. However, even after 15 years using this system weedy rice is commonly found in the rice areas and is still reported as one of the most important problems of this crop mainly due to imidazolinone resistance. Despite the problems of herbicide resistance, Merotto Junior et al. (2016) estimated that the utilization of the Clearfield ${ }^{\star}$ System provided an increase of $2,000 \mathrm{~kg} \mathrm{ha}^{-1}$ in rice yield due, mainly, to weedy rice control, better use of the fertilizers by the crop in comparison with weedy rice infested areas, and adequate timing of sowing in comparison with delayed seeding caused by two or three soil disk harrowings aimed at eliminating weedy rice.

Problems caused by barnyardgrass are also related to the severe interference when one plant $/ \mathrm{m}^{-2}$ competing with different management technological levels led to grain yield losses from $5 \%$ to $15 \%$ (Richter et al., 2019). In addition, the large number of mentions of the presence of this weed may also be due to the number of herbicide resistance cases. In this region, imidazolinone resistance was found in $81 \%$ of 624 evaluated populations (Matzenbacher et al., 2015), and multiple resistance to three action mechanisms was recently identified in the state of Santa Catarina (SC) (Eberhardt et al., 2016). Also, both weeds are reported as resistant to the imidazolinone herbicides (Heap, 2020), which make them difficult to control chemically. In addition, problems with the Cyperus species were also cited several times by the farmers surveyed. This is certainly related to the recent occurrence of resistance to imidazolinone herbicides (Ulguim et al., 2017). The importance of the infestations with Cyperus species was much lower in the beginning of the Clearfield utilization 15 years ago, and this can be considered as one of the changes that occurred associated with the herbicide use and weed dynamics. However, the Cyperus species on rice has been chemically controlled predominantly by using ALS-inhibitor herbicides since the 1980's, which could also have contributed to these changes.

The main reasons for the low efficacy of weed control indicated by the consultants are late herbicide application with weeds in advanced developmental stages, herbicide resistance and delay in the beginning of flooding (Figure $2 b)$.Thus, except for the herbicide resistance, the reasons for low efficacy of weed control appear to be the same that were reported before the beginning of Clearfield ${ }^{\circledR}$ rice (Agostinetto et al., 2001), indicating that farmers still do not use the principles of adequate herbicide application and integrated weed management. Proper understanding of factors that lead to failure in weed control includes knowledge regarding the distribution of species in the rice crop areas, and its relationship to causes that trigger this problem. Results of non-metric multidimensional scaling showed little or no tendency of the predominance of a species in a certain region, a fact that denotes an almost homogeneous distribution of the main weeds in the state of RS (Figure 3a).

Barnyardgrass was aligned predominantly with the second axis (NMDS2) according to its positive value, while smallflower umbrella-sedge (Cyperus difformis L.) was less related to this axis with a negative value. Nevertheless, crabgrass (Digitaria sp.) was more aligned with the first axis (NMDS1), while weedy rice and barnyardgrass were less situated along this axis. In addition, crabgrass and smallflower umbrella-sedge were more correlated with the ordination in the first axis (Figure 3a).

Taking into consideration the ordination between species and causes that lead to low control efficacy, the more important weeds were grouped closer to the main reasons of failure. Barnyardgrass and weedy rice were grouped with advanced stage of control, inadequate environmental conditions, and delay in the beginning of flooding in the second axis (Figure $3 \mathrm{~b}$ ). In addition, herbicide resistance showed a greater correlation with managements than with the different species evaluated. This indicates that herbicide resistance is currently associated with several species, differently from the situation when the Clearfield system began to be utilized where it was considered a major problem only in Echinochloa sp.

a)

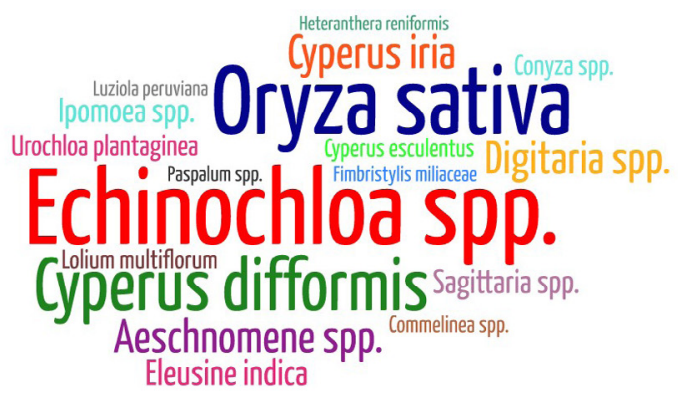

b)

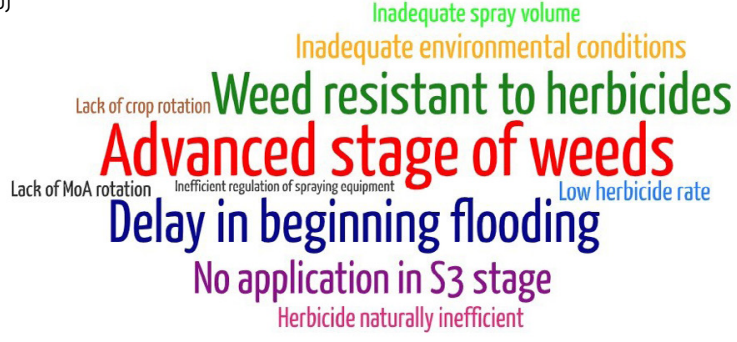

Figure 2 - Most weed species cited (a) and reasons for the low efficacy of weed control (b) in Clearfield ${ }^{\circ}$ rice in RS ( $n=103)$ 
The rice flatsedge (Cyperus iria L.) and crabgrass were more correlated with the ordination in the first axis (Figure $3 b)$. These species were negatively related to weedy rice. In most situations, rice flatsedge and crabgrass are found in rice fields that are rotated with soybean and pastures, and these crop systems contribute to decreasing the weedy rice infestations (Marchesan et al., 2011; Ulguim et al., 2018). Besides, yellow nutsedge, crabgrass and jointvetch (Aeschynomene spp.) and the absence of herbicide application at the $S_{3}$ stage (Counce et al., 2000) were aligned with the first axis. The application at the $S_{3}$ stage corresponds to a non-selective herbicide applied after sowing the rice and before emergence focused mainly on controlling emerged

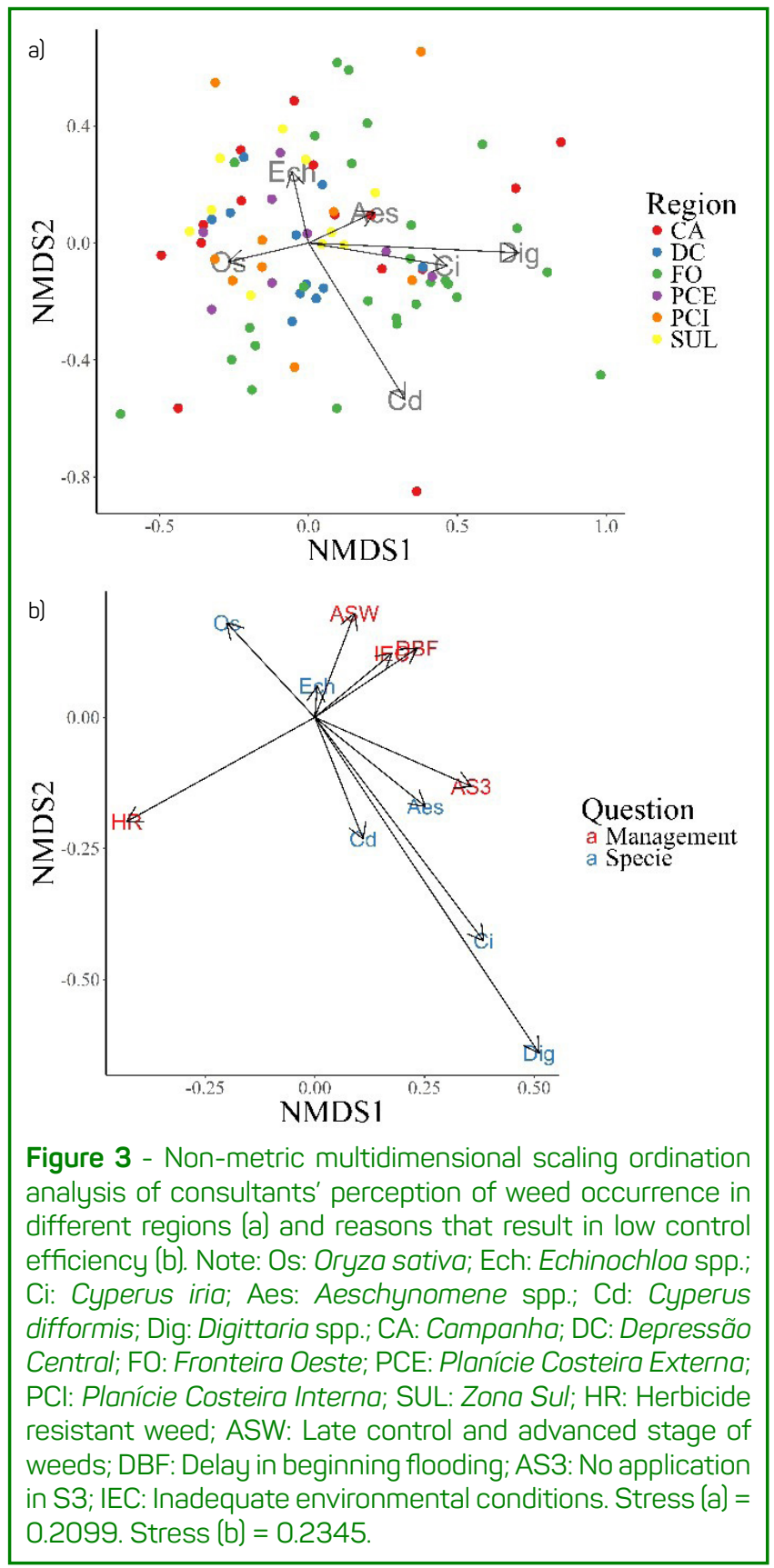

weedy rice. The occurrence of yellow nutsedge and joinvetch were not related to herbicide resistance. However, there are some studies that demonstrate the lack of efficiency of imidazolinones on joinvetch (Scherder et al., 2001) and sedges (Pellerin et al., 2003). In addition, a study identified the occurrence of herbicide resistance in rice flatsedge on Clearfield ${ }^{\circ}$ rice in Brazil (Chiapinotto et al., 2017).

When consultants' were asked about herbicide resistance, $93 \%$ answered that this problem had increased in flooded rice; and 58\% and 35\% stated that the area and number of cases, respectively, have expanded (Figure 4a). On the other hand, only $7 \%$ reported that the problem of resistance had stabilized. The most frequent weed species with herbicide resistance in rice areas are weedy rice, barnyardgrass and Cyperus sp. (Figure 4b). This result confirms the perception of consultants about weed occurrence in Clearfield ${ }^{\circ}$ rice fields (Figure 2a), indicating that the current major problem of weed management is herbicide resistance. This is associated with the high

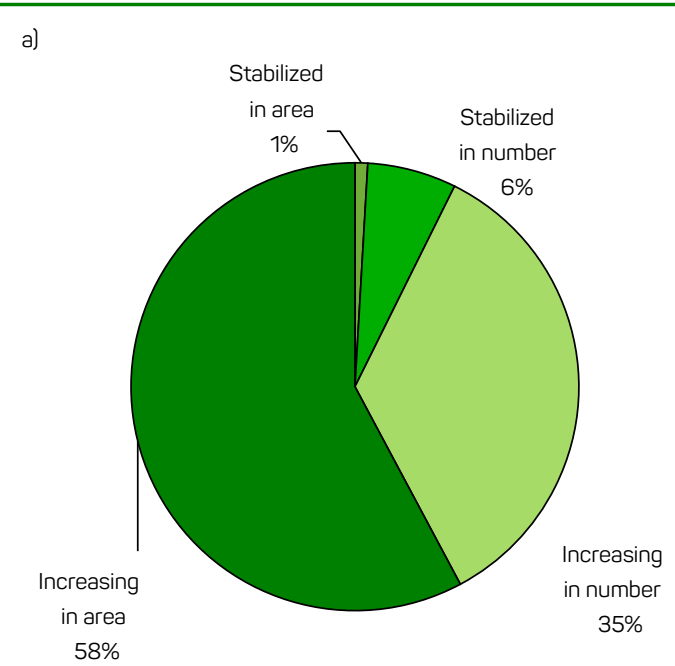

b)

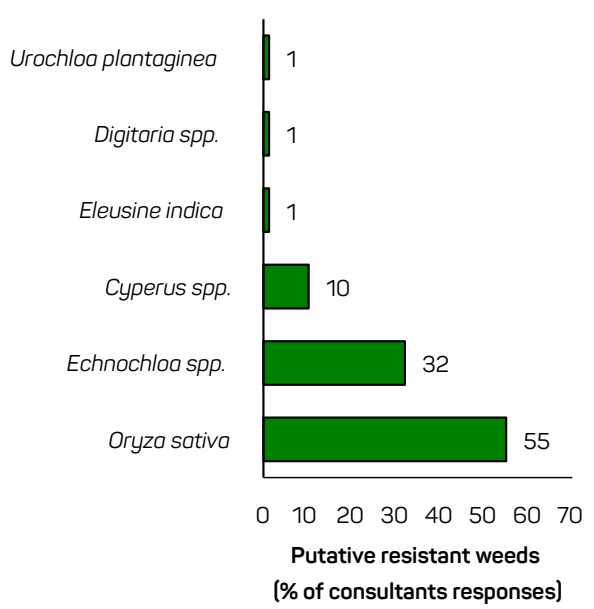

Figure 4 - Consultant's perception of the evolution of weed resistance in flooded rice in RS (a) and putative weed resistant species (b) $(n=101)$. 
number of herbicide-resistant weeds in rice in Brazil, with nine cases reported considering different species and herbicide combinations (Heap, 2020).

Consultants have the perception of seven important weed species with herbicide resistance to four modes of actions (Table 1). Resistance of weedy rice to ALS inhibitors is the most frequent problem, followed by Echinochloa sp. resistance to these herbicides and quinclorac (cellulose biosynthesis inhibitor). The resistance to EPSPs inhibitor in Echinochloa sp. is reported by five percent of the consultants, although this resistance has not yet been documented for rice in the evaluated region. Resistance of Conyza sp. and Lolium multiflorum L. is reported by 46 and $42 \%$ of the respondents, respectively. These problems are not directly related to the rice crop, since Conyza sp. occurs in soybean cultivated in crop rotation and L. multiflorum is used as a winter pasture (Marchezan et al., 2011). The main result of the perception of herbicide resistance is that $81 \%$ of the consultants indicated the occurrence of imidazolinone resistance of weedy rice

\begin{tabular}{|c|c|c|c|c|}
\hline \multirow{3}{*}{ Weed species } & \multicolumn{4}{|c|}{ Herbicide mode of action } \\
\hline & $\begin{array}{c}\text { Cellulose } \\
\text { biosynthesis }\end{array}$ & $\begin{array}{c}\text { ALS } \\
\text { inhibitors }\end{array}$ & $\begin{array}{l}\text { ACCase } \\
\text { inhibitors }\end{array}$ & $\begin{array}{c}\text { EPSPs } \\
\text { inhibitors }\end{array}$ \\
\hline & \multicolumn{4}{|c|}{$\%$} \\
\hline Echinochloo spp. & 43 & 49 & 19 & 5 \\
\hline Cyperus spp. & 0 & 30 & 0 & 0 \\
\hline Oryzo sativo & 0 & 81 & 0 & 0 \\
\hline Conyzo spp. & 0 & 0 & 0 & 46 \\
\hline Loliummultiflorum & 0 & 0 & 0 & 42 \\
\hline Eleusine indico & 0 & 0 & 0 & 10 \\
\hline Sogittoria spp. & 0 & 10 & 0 & 0 \\
\hline$n=102$ & & & & \\
\hline
\end{tabular}

${ }^{1}$ acetolactate synthase inhibitors, acetyl coenzyme-A carboxylase inhibitors, 5-enolpyruvylshikimate-3-phosphate synthase inhibitors. and that barnyardgrass is resistant to herbicides in four modes of actions. In this sense, Eberhardt et al. (2016) reported the occurrence of Echinochloa crus-galli biotypes with multiple resistance to three of the aforementioned modes of herbicidal action (cellulose biosynthesis, ALS and ACCase inhibitors) in the state of SC.

Integrated weed management is necessary to change the present situation of weed resistance to herbicides in irrigated rice. The difficulties of crop rotation in most rice areas in south Brazil result in continuous rice monoculture (Marchesan et al., 2011) and low diversity of herbicide mode of action used. These difficulties are greater in flooded rice compared with other row crops. Therefore, consultant and farmer training and awareness-building are essential to improve the adoption of such necessary integrated weed management measures. According to consultants, the predominant rice establishment system of Clearfield ${ }^{\circ}$ rice is minimum tillage performed in autumn in major areas and on summer in smaller areas on farms (Table 2). Sowing with no-tillage after soybean is used in $25 \%$ of the area and no-till in monoculture rice cases is nonexistent in almost half of the cases. Integrated agricultural production systems with higher intensity of crop rotation have suffered greater infestation with perennial species and less with weedy rice and barnyardgrass (Ulguim et al., 2018). The most frequent use of areas during off-season is fallow and livestock (Table 2). The widespread adoption of fallow is a strategy that may potentially increase the weed problems.

The results of this study indicated that the main weeds found in Clearfield ${ }^{\circ}$ rice are weedy rice and barnyardgrass, and the main reasons for low efficacy of weed control are resistance to herbicides, delay in beginning flooding and application to plants at advanced stages of development. The herbicide resistance problem is increasing in number of cases and rice area of RS after fifteen years using the Clearfield ${ }^{\circ}$ System. The predominant rice establishment systems are the conventional disk harrow and plowing. The change in weed flora and the occurrence of herbicide

Table 2. Proportion of rice establishment systems in Clearfield ${ }^{\circ}$ rice fields in RS and off-season management according to consultants' responses.

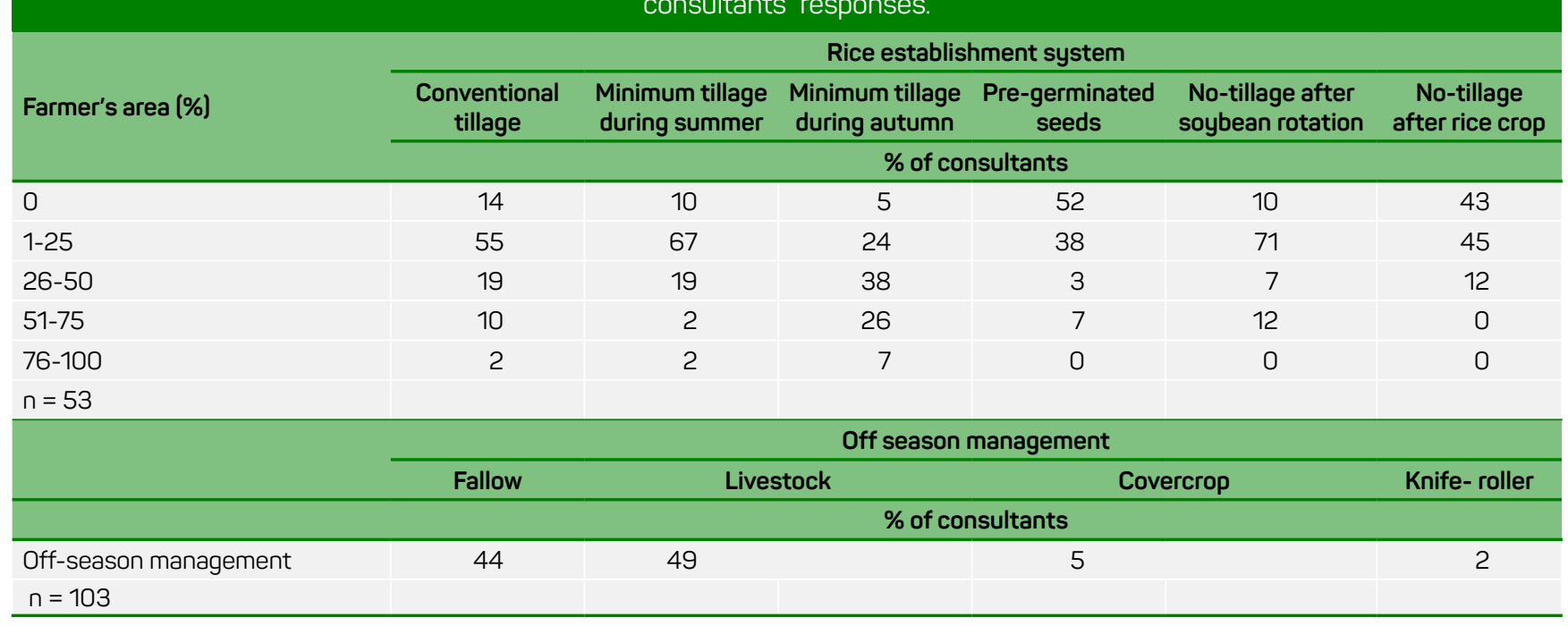


resistance is more related to the pattern of herbicide use than to crop or other weed management practices.

Crop rotation is used partially in Clearfield ${ }^{\circ}$ rice fields, and the predominant rice establishment system is the minimum tillage performed in summer or autumn. The Clearfield System provided and increased rice grain yield due to better weed control and crop management at the beginning of its utilization. Nowadays, some farmers still benefit from these advantages, but the sustainability and broad benefits depend on crop rotation and integrated weed management.

\section{Authors' contributions}

All authors contributed equally to the conception and writing of the manuscript.

\section{Acknowledgments}

The authors are grateful to all the consultants who took the time to complete the survey, especially at IRGA's Division of Technical Assistance and Rural Extension (DATER).

\section{Funding}

This research received funding from "Fundação de Amparo à Pesquisa do Estado do Rio Grande do Sul (FAPERGS)", Edital $01 / 2017$.

\section{References}

Agostinetto D, Fleck NG, Rizzardi MA, Merotto Jr A, Vidal RA. [Red rice: ecophysiology and strategies of control]. Cien Rural. 2001;31(2):341-9. Portuguese. Available from: https://doi.org/10.1590/S0103-84782001000200026

Agro Basf Brasil. [Clearfield ${ }^{\circledR}$ Production System: the main rice production system]. [cited 2020 Feb 18]. Portuguese. Available from: https:// agriculture.basf.com/br/pt/protecao-de-cultivos-e-sementes/produtos/clearfield.html

Beckie HJ, Hall LM. Genetically-modified herbicide-resistant (GMHR) crops a two-edged sword? An Americas perspective on development and effect on weed management. Crop Prot. 2014;66(1):40-5. Available from: https://doi.org/10.1016/j.cropro.2014.08.014

Burgos NR, Norman RJ, Gealy DR, Black H. Competitive N uptake between rice and weedy rice. Field Crops Res. 2006;99(2-3):96-105. Available from: https://doi.org/10.1016/j.fcr.2006.03.009

Chiapinotto DM, Schaedler CE, Fernandes JPS, Andres A, Lamego FP. Cross-resistance of rice flatsedge to ALS-inhibiting herbicides. Planta Daninha. 2017;35: e017166827. Available from: https://doi.org/10.1590/s0100-83582017350100068

Companhia Nacional de Abastecimento - Conab. [Brazilian crop monitoring report 2017/18], v. 10, n. 10, Jul. 2018. Portuguese. Dados de safra. https://www.conab.gov.br/info-agro/safras/graos/boletimda-safra-de-graos/item/download/21088_8ca248b277426bb3974f74efaOOabab6. Accessed: August 7, 2018

Companhia Nacional de Abastecimento - Conab. [Brazilian crop monitoring report 2019/2020]. [cited 2020 Apr 2]. Portuguese. Available from: https://www.conab.gov.br/info-agro/safras

Counce PA, Keisling TC, Mitchell AJ. A uniform, objective, and adaptive system for expressing rice development. Crop Sci. 2000;40(2):43643. Available from: https://doi.org/10.2135/cropsci2000.402436x

Eberhardt DS, Oliveira Neto AM, Noldin JA, Vanti RM. Barnyardgrass with multiple resistance to synthetic auxin, ALS and ACCase inhibitors. Planta Daninha. 2016,34(4):823-32. Available from: https://doi.org/10.1590/s0100-83582016340400023
Edwards CB, Jordan DL, Owen MDK, Dixon PM, Young BG, Wilson RG, et al. Benchmark study on glyphosate-resistant crop systems in the United States. Economics of herbicide resistance management practices in a 5 year field-scale study. Pest Manag Sci. 2014;70(12):19249. Available from: https://doi.org/10.1002/ps.3759

Fruet BL, Merotto Junior A, Ulguim AR. Survey on rice weed management and public and private consultant characteristics in Southern Brazil. Weed Technol. 2020;34(3):351-356. Available from: https://doi.org/10.1017/wet.2019.115

Goulart ICGR, Menezes VG, Bortoly ED, Kupas V, Merotto Junior A. Detecting gene flow from ALS-resistant hybrid and inbred rice to weedy rice using single plant pollen donors. Exp Agric. 2016;52(2):237-50. Available from: https://doi.org/10.1017/S0014479715000058

Heap I. The international herbicide-resistant weed database: online. 2020 July 23. Available from: https: www.weedscience.org

Kenkel NC, Derksen DA, Thomas AG, Watson PR. Review: multivariate analysis in weed science research. Weed Sci. 2009;50(3):281-92. Available from: https://doi.org/10.1614/0043-1745(2002)050[0281:RMAIWS]2.0.CO;2

Marchesan E, Massoni PFS, Villa SCC, Grohs M, Avila LA, Sartori GMS, et al. [Productivity, injury and control of red rice in succession of irrigated rice cultivation in System Clearfield ${ }^{\circ}$. Cienc Rural. 2011;41(1):17-24. Portuguese. Available from: https://doi.org/10.1590/S0103-84782011000100004

Matzenbacher FO, Bortoly ED, Kalsing A, Merotto A. Distribution and analysis of the mechanisms of resistance of barnyardgrass (Echinochloo crus-galli) to imidazolinone and quinclorac herbicides. J Agric Sci. 2015;153(6):1044-58. Available from: https://doi.org/10.1017/S0021859614000768

Menezes VG, Mariot CHP, Kalsing A, Goulart ICGR. [Red rice (Oryzo sotivo) resistant to the herbicides imidazolinones]. Planta Daninha. 2009;27(Spe):1047-1052. Portuguese. Available from: https://doi.org/10.1590/S0100-83582009000500018 
Merotto Junior A, Goulart ICGR, Nunes, AL, Kalsing A, Markus C, Menezes VG, et al. Evolutionary and social consequences of introgression of nontransgenic herbicide resistance from rice to weedy rice in Brazil. Evol App. 2016;9(7):837-46. Available from: https://doi.org/10.1111/eva.12387

Nunes AL, Markus C, Delatorre CA, Merotto Junior A. Nucleotide variability and gene expression reveal new putative genes related to seed shattering in weedy rice. Ann Appl Biol. 2015;166(1):39-52. Available from: https://doi.org/10.1111/aab.12159

Oksanen J, Blanchet GF, Friendly M, Kindt R, Legendre P, Mcglinn D, et al. Vegan: community ecology package. R package version 3.4.4. 2018 [cited 2018 Dec 14]. https://CRAN.R-project.org/package=vegan.

Pellerin KJ, Webster EP, Zhang W, Blouin DC. Herbicide mixtures in water-seeded imidazolinone-resistant rice (Oryzo sativa). Weed Technol. 2003;17(4):836-41. Available from: https://doi.org/10.1614/wt-03-007r1

Riar DS, Norsworthy JK, Steckel LE, Stephenson DO, Bond JA. Consultant perspectives on weed management needs in Midsouthern United States cotton: a follow-up survey. Weed Technol. 2013b;27(4):778-87. Available from: https://doi.org/10.1614/WT-D-13-00070.1

Riar DS, Norsworthy JK, Steckel LE, Stephenson DO, Eubank TW, Bond $\mathrm{J}$, et al. Adoption of best management practices for herbicide-resistant weeds in Midsouthern United States cotton, rice, and soybean. Weed Technol. 2013a;27(4):788-97. Available from: https://doi.org/10.1614/WT-D-13-00087.1

Richter GL, Streck NA, Zanon AJ, Ulguim AR, Kruse ND, Santos GAA, et al. Introducing rice yield loss caused by weed competition into the SimulArroz model. Pesq Agropec Bras. 2019;54:e01418. Available from: https://doi.org/10.1590/s1678-3921.pab2019.v54.01418

Scherder E F, Talbert RE, Lovelace ML, Buehring NW. Weed control programs in herbicide-tolerant rice. Proc South Weed Sci Soc. 2001;54(1):39-40.

Ulguim AR, Agostinetto D, Vargas L, Silva JDG, Silva BM, Westendorff NR. Agronomic factors involved in low-level wild poinsettia resistance to glyphosate. Rev Bras Cienc Agrar. 2017;12(1):51-9. Available from: https://doi.org/10.5039/agraria.v12i1a5423

Ulguim AR, Carlos FS, Santos RAS, Zanon AJ, Werle IS, Beck M. Weed phytosociological in irrigated rice under different cultivation systems and crop rotation intensity. Cienc Rural. 2018;48:e20180230. Available from: http://dx.doi.org/10.1590/0103-8478cr20180230

Ulguim AR, Silva BM, Agostinetto D, Avila Neto RC, Zandoná RR. Resistance mapping of the genus Cyperus in Rio Grande do Sul and selection pressure analysis. Planta Daninha. 2019;37:e019186679. Available from: http://dx.doi.org/10.1590/s0100-83582019370100062

WordArt. Cited: 2020 Feb 1. Available from: https://wordart.com/ 